\title{
Impacts of the globalized economy on the environment: the tanning industry in the Vale do Rio dos Sinos
}

\author{
Figueiredo-Sganderla, JA. ${ }^{\mathrm{a} *}$, Prodanov, $C C .^{\mathrm{a}}$ and Daroit, $D .{ }^{\mathrm{b}}$

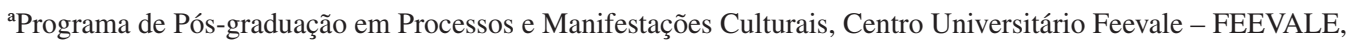 \\ Rod. RS-239, 2755, CEP 93352-000, Novo Hamburgo, RS, Brazil

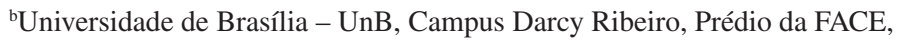 \\ Asa Norte, CEP 70910-900, Brasília, DF, Brazil \\ *e-mail: sganfigue@feevale.br
}

Received February 21, 2010 - Accepted April 29, 2010 - Distributed December 31, 2010

(With 1 figure)

\begin{abstract}
This case study analysed the impact of the global economy on the environment of the Vale do Rio do Sinos region in southern Brazil. Interviews and questionnaires were used to collect data from social, cultural, economic and political agents in this region, and documents about the tanning industry were reviewed and analysed. Global perspectives and local conditions were brought together to understand the causes and consequences of social, political and economic structures and to evaluate the intrinsic association of the tanning industry with the social, historical and cultural development of the Vale do Rio dos Sinos. The behaviour of the local community, where individuals believe that progress is primordially based on industrial development and go to any lengths to achieve it, was also studied. The analysis of industries that have a high contamination potential revealed that dirty industries moved from central to peripheral countries up to the 1980 s, but movement is currently internal and occurs between states in Brazil due to several types of incentives.
\end{abstract}

Keywords: environment, globalisation, risks migration, industrialization.

\section{Impactos da economia globalizada no meio ambiente: as indústrias curtidoras no vale do rio dos Sinos}

\begin{abstract}
Resumo
Este trabalho indaga os impactos da economia global para o meio ambiente na região do vale do rio dos Sinos, Brasil. É um estudo de caso que se apoiou em 32 entrevistas; 307 questionários, aplicados aos atores socioculturais, econômicos e políticos; além de observação e documentos, relacionados à indústria curtidora. A proposta consiste em aproximar o global ao local, percebendo as causas e consequências da estrutura social, política e econômica. Em relação à indústria de curtumes, veremos que a mesma está intrínseca no processo de formação sócio-histórico e cultural da comunidade do vale do rio dos Sinos. Por outro lado, essa sociedade acredita que o progresso tem sua base no desenvolvimento industrial, não medindo esforços para alcançá-lo. Perceberemos, também, um movimento de migração de indústrias com alto potencial de contaminação. Os dados apontam que, até a década de 80, o que víamos dos países de centro (principalmente Europa) deslocar suas indústrias sujas para os países de periferia; hoje, por muitos incentivos de ordens diversas, assinala-se essa migração internamente entre os estados do Brasil.
\end{abstract}

Palavras-chave: meio ambiente, globalização, migração de riscos, industrialização. 


\section{Introduction}

Since the 1990s, the Brazilian economy has been undergoing significant transformations, mainly due to the process of opening up to international trade. Specifically the Vale do Rio dos Sinos (Sinos River Valley) (VS), an important footwear producing region and one that has hosted a cluster in this sector since the 1950s, has become the largest Brazilian exporter of leathers, and this economical liberalisation of the 1990s brought about consequences that have been expressed, and are still expressed, as exacerbated competition, regarding both foreign and domestic markets.

One of the most worrying issues of this liberalisation that has been motivated by international policy has been, and still is, the internal dispute between several states of the Brazilian federation, in their competition for "industrial plants". Most of these were relocating in search of lowercost labour and, usually, to escape increasingly demanding environmental legislation, due to their great impact on the environment, as well as their need for raw materials and their high polluting potential.

This "progress" has unleashed an illusionary situation of development, in which governments do not have any control on contractual relations, and the impositions by multinational corporations cause a vicious marketing cycle, by directly attacking the organisational labour structure. Could this, more precisely, be a fight without opponents? A "suicidal war"?

The analysis in this text starts with the elements that serve as a foundation to the globalisation of the economy, its controversies and distortions; the division of labour and the concentration of capital in only a few countries that own technology. Is the "utilitarian plan" the ideal one for Brazilian reality? Is it correct to claim that the migration of dirty industries to undeveloped countries would improve worldwide well-being? Is the environmental havoc minute, as compared to the economical gains? After all, can there be harmony between industrial development and the conservation of the environment, as signalled by neoclassical theory?

Thus, the present article attempts to discuss the influence of globalisation on the leather sector in the Vale do Rio dos Sinos (VS) and on how this industrial complex has been positioning itself in respect to the effects of this phenomenon. A few data indicate that the direct influence of globalisation, since the 1990s in Brazil, has caused serious problems, among which problems relating to an increase in production with a decrease in the number of jobs. This leads us to the hypothesis that the volume of emissions harmful to the environment have increased per employed worker. Another assumption that becomes even more questionable is related to the idea that international trade or globalisation may provide opportunities and ensure equality and environmental protection.
The focus of this work is on the Vale dos Sinos and specifically on the tanning industry, due to the importance of this region and this sector in the national economical context. The orientation toward exports and the high polluting potential of the tanning industry have made it the appropriate object of investigation in order to learn more on the dynamics of globalisation and its influence on the context of a developing country such as Brazil.

The Vale do Rio do Sinos (VS) is located in the state of Rio Grande do Sul. Its territory covers $1,398.5 \mathrm{~km}^{2}$, and includes a total of 14 municipalities ${ }^{1}$. The present population is $1,287,805$ inhabitants $^{2}$, with a demographical density of 910.7 inhabitants $/ \mathrm{km}^{2}$, of which $90.6 \%$ live in urban areas and $9.4 \%$ are in rural areas; the illiteracy rate is $4.8 \%$, (FEE, 2009). Regarding the tanning industry, the largest number of factories is concentrated in the state of Rio Grande do Sul, summing up to 217 tanneries; and more than $60 \%$ of them are installed in the Vale do Rio dos Sinos. The number of workers is also significant, a total of 15,821 workers, representing $35 \%$ of Brazilian workers in this area (RAIS, 2008). According to Francischini and Azevedo (2003), in relation to the leather and footwear sector, the region is responsible for $40 \%$ of the country's production and responds for $80 \%$ of exports, which corresponds to approximately $1 \%$ of the Brazilian GNP.

Given the magnitude of the industry and aiming at answering the questions proposed in this work, we have tried to approximate the macro-sociological theories to the reality of the tanning industry in the VS. The chosen research method was the case study, both qualitative and descriptive. The research techniques used were 32 open interviews and 307 applied questionnaires. The interviewees are linked to the social-cultural, economical and political agents and are divided into: workers, public administration, NGOs, neighbours and factory owners, with emphasis on the private experiences of the players, of their feelings, of how they perceive the development of the tanning industry and its risks, how they interact and, above all, what actions they perform regarding this sector. In this article, the speeches of public administrators and business people are privileged, since their position affects the whole tanning sector, in a direct and quick manner. Given the number of interviews (32), we will not identify the interviewees; thus, the fragments of the interviews used in the text correspond to the direct connection with the problem of the proposed research.

\footnotetext{
'Araricá, Campo Bom, Canoas, Dois Irmãos, Estância Velha, Esteio, Ivoti, Nova Hartz, Nova Santa Rita, Novo Hamburgo, Portão, São Leopoldo, Sapiranga and Sapucaia do Sul.

${ }^{2}$ In this region, attention is drawn on its territory and population. The Vale do Sinos occupies roughly $0.5 \%$ of the RS state territory, while the population is approximately $12 \%$ of the population of Rio Grande do Sul. This means that it is an industrial region that has concentrated a great percentage of the state population on a very small territory. (Data: www.ibge.gov).
} 


\section{The Relationship Between Industrial Development and Environmental Issues: the Tanning Industry of the Vale dos Sinos}

Economic theories and models, and the predominant policies implemented at the end of the 1970s, throughout the 1980 s and especially the 1990 s, being facilitated by the new technologies, comprise part of the main landmark for the most recent concept and development of the socalled phenomenon of globalisation. The evolution of this process has been marked by, among other things, the deepening of the internationalisation of the economy, as well as by serious discussions in the sphere of the General Agreement on Trade and Tariffs (GATT), culminating, in 1995, with the creation of the World Trade Organisation (WTO), an institution responsible for the liberalisation and promotion of international trade.

The foundation of this new model of remote policy goes back to the thoughts of David Ricardo, with the proposal of the theory of comparative advantages. According to this theory, each country should produce those goods that imply a cost of opportunity that is comparatively lower than what is required by other economies in order to produce the same good. The author considers that this process results in a productive specialisation and that the marketing of these products via international trade would lead to an accumulation of capital capable of incrementing the quality of life of populations ${ }^{3}$.

The idea regarding the benefits of free trade and its double role in the development was being formulated. This would consist, on one hand, of the fact that the prices of products would be determined by the market conditions, and on the other hand, that the inefficient sectors of the economy would be gradually replaced by others. In short: specialisation and free international trade would lead to a situation of optimum balance of the worldwide economy; this type of economic policy would allow us to act on the powers of markets.

Without going into it too deeply, one realises that the core of neoclassical theory constitutes the theoretical support that was the basis for the free trade agreements since the creation of the WTO. Based on free-trade agreements, nations committed through their participation in international trade to improve the quality of life of people, by generating a larger number of jobs, with higher wages, and incrementing the supply and demand of goods. According to these agreements, goals should be reached without wasting world resources, aiming for sustainable

\footnotetext{
${ }^{3}$ What is perceived regarding this "theory of comparative advantages", and as the available data show, is that prices of products are not necessarily those determined by the market, and neither are the conditions for their production. Below are some characteristics that deny this theoretical assumption: a) The prices of products do not include the environmental costs of the productive chain; b) the cost of labour is not uniform; c) countries do not have the same advantages; d) the dynamics of technological development of each product are not uniform either; e) markets develop unequally; and f) financial capital is not static. According to Ferré (2003), the prices of products result from a complex relationship between production costs, supply, demand and power relationships.
}

development, by conserving and protecting the environment. The peak would be in incrementing the means in a manner compatible with local needs, in the specificity of economic development of the nations in their ensemble.

With the goal of increasing the use of the neoliberal manual, the WTO put its efforts into promoting free trade according to the policies of the developed economies and did so without considering the productive, technological, professional and financial imbalances of the world. By following this logic, the neoliberal foundation has assumed the condition of exclusivity in the negotiations between countries, generating significant advances regarding liberalisation (commercial, financial, productive and technological $)^{4}$.

It is certain that the neoliberal rhetoric applied during the 1990s has been articulated both on an international and on a national level. It the case of Brazil, the application of this neoliberal prescription was backed by the communications media, who emphasised the supposed advantages regarding the modernisation of the productive park and the generation of better work positions. Thus, the articulation with the external plan through financial help policies by the World Bank and the International Monetary Fund (IMF) found fertile terrain and conditioned an economic liberalisation without restrictions, and without considering possible forms of resistance.

In the Brazilian case, initially monetary stabilisation of the dollar is pursued, which was indispensable for the multinational corporations to evaluate their revenue, costs of production and services, etc., followed by liberalisation in several spheres:

- Commercial: with the reduction of import duties and without a larger supply of exported products, there has been an increase in the supply of imported products, leading the Brazilian economy (which was the third largest producer of exportable surplus in the world) to a deficit in the balance of trade, a situation that generates an increase in foreign $\mathrm{debt}^{5}$. On the basis of this question are background inconsistencies of the neoclassical

\footnotetext{
${ }^{4}$ In the multilateral plan, in general, within the proposal from the WTO, regional schemes have been set up, such as the European Union (EU), the North American Free Trade Association (NAFTA) and MERCOSUR, and the discussion on the creation of the Free Trade Association of the Americas (FTAA) has been introduced.
}

\footnotetext{
${ }^{5}$ The surpluses of the balances of trade registered between the years of 1983 and 1994 were replaced by repeated deficits. In fact, in the first period mentioned, the efforts toward building large surpluses in foreign trade had not been sufficient to balance the services account and the balance of payments, and for this reason there have been an average of transfers of $4.1 \%$ of GNP to abroad, increasing external debt by 54.7 billion dollars, going from 93.6 to 148.3 billion dollars. The deficit between the years of 1995 and 1999 was five billion dollars per year, with an annual average in services of 23.3 billion dollars, which had been 13.9 billion dollars between 1983 and 1984. Thus, the annual deficit reached an amount of 28.3 billion dollars, which once again was financed with external indebtedness, increasing the debt from 148.3 to 239.9 billion dollars ( 88.6 billion dollars in five years) (Pochmann, 2001).
} 
theory which considers that countries can converge in advantages, in technological development and in the development of markets. The results of the neoliberal policies in countries with economical conditions of absolute disadvantages are devastating, as we will see. Regarding this, we could use Ferré's (2003) scheme, which, through consistent data, shows that the prices of products, which are played in unequal market conditions, are not necessarily determined by the market, and that, on the contrary, result from a complex relationship between costs of production, supply, demand and power relationships.

- Financial: the so-called "autonomy of the central bank" consisted of financial liberalisation. With practices such as high interest rates we aimed at attracting capital, with the goal of balancing the deficit and the increase of external debt. The financing of the commercial deficit and of the balance of payments has been associated with external indebtedness, both in the public and the private sector, and the attraction of voluntary resources due to high interest rates. The mobility of financial capital is one of the contradictions of neoliberalism: its disproportionate volume and its uncontrollable mobility alter market and production price conditions. In Brazil, fear of financial instabilities is still latent, with the danger of aggravating the problems that have already been mentioned and those pending development.

- Internationalisation of the productive process: this is related to the opening up to foreign capital in the form of so-called "foreign investments" which have constituted the appropriation of public assets (privatisation) ${ }^{6}$ as well as private assets by international capital, which have internationalised the production of food, automobiles, computing components, pharmaceutical, hygiene products, plastics, alcohol beverages and other products. The problem consists of placing under internal competition economies with gigantic disparities; by relating the non-uniform labour cost to the technological production differences: as if the deficit in the commercial balance and the balance of payments were not enough, we can observe the reorientation of productive systems, which disarticulates certain chains and intensifies primary production, a consequence of the irrational deindistrialisation process. This is due to technological deficit and the obligation of playing on the plane of competition, by means of the exploitation of labour and the degradation of the environment.

\footnotetext{
${ }^{6}$ Deák (2000) proposes the possibility that in Brazil the concept of globalisation has become an excuse to privatize public assets, thus abandoning the responsibility and sovereignty in the domestic market; this globalisation is nothing but a disguised form of "delivery" of the domestic capital.
}

This policy of internationalisation of productive systems and competitiveness through environmental subventions is favoured by the "fiscal war" between states ${ }^{7}$, which would inexplicably act as main promoters. The states start generating conditions to receive companies, which in their majority are of international origin, with demands for raw material and with a high potential for polluting the environment. However, the states do not have the power of decision in the formalisation and implementation of certain investments; so the demands for the government vary: granting of the plot of land, incentives in the construction of the plant and tax exemption for a long period of time.

Thus, the economical crisis that the VS is undergoing is justified, and is a result, among other things, of the policies established in the international market, which in turn transferred industries to Latin America, in search of advantages; at present, the difference is that the advantages are located in other countries, such as China, which have, above all, cheap labour, and which are tangibly and forcefully experiencing the development process of first modernity, namely industry. In this case, the difficulties increase when the northern, northeastern and central-west regions of Brazil also enter the competition and, supported by this "fiscal war" and due to a lack of joint commitment to the country, facilitate the arrival of industries, and give tax exemption and facilitate licenses without a commitment of environmental control for such free implementation. According to a study by CETESB (2005), ${ }^{8}$ a decrease in tanneries in the state of São Paulo has been observed over the last few years (the case is similar to that of the state of Rio Grande do Sul) in view of the contraction of the economy, the increase in competition, the closing of a few markets; and mainly due to benefits obtained when migrating to other states. The governments, represented in the sub-sample of representatives of public administration, are conscious and all talk about the problem of "fiscal war" that exists in Brazil; which is something that draws attention and differs between interviews, in which the interviewee quoted below calls these facts suicidal war.

An example is the Northeast, where wages are lower, and where there are state subsidies, in other words, a 'fiscal war' and this has to end urgently in Brazil, since it is not wise for a government to obtain 300 jobs and, on the other hand, lose 300 jobs. Under this logic, the country gets unemployment for a certain number of workers and employs the same number, hence there is no evolution; it is even a negative situation, because the local government grants fiscal incentives which cause vicious processes within the companies, since, when the period of contract elapses they migrate to another region. The real loser is the population which sees no improvements in education, security, etc. This is a suicidal war, I may be able to do something today,

${ }^{7}$ Brazilian states are autonomous federative units, which means, "self government", "self-legislation", and "self-tax collection". Brazil has 27 federative units.

${ }^{8}$ Environmental Technology and Sanitation Company. 
but the next day it is the other guy's turn; things may take long to happen, but the moment will arrive when we all suffer the consequences. (Interview with a representative of Public Administration)

It is a matter of economical and administrative attitudes, in other words, and people hold the local government responsible for not meeting business people's needs and things are also blamed on the "Major State" (the nation) for the lack of centralised power and for the attitudes of other states. The question would be: What is going on in other Brazilian states regarding fiscal incentives, and was this not, in the past, one reason for the industrial development in the VS? The process of internationalisation of the economy is extensive and that which happened in the 1970s, especially in Rio Grande do Sul, is now happening to the industrial development of the northeastern states. The problem is that the environment may suffer the consequences of purely economical government purposes. This fragment of a quote represents complaints of most industrialists, evidenced in the subsample of the interviewees.

We are not producing much, and are waiting for this short-vision economic policy to end, this vision of the next election, unfortunately this is the way the country is, the vision of the Brazilian politician is on the next elections, they do not have long-term vision. They are killing the sector, one issue is the monetary subject, ICMS, etc.; last year we closed the balance sheet of the company and a third of the assets was in PIS, COFINS and ICMS and this strangles the companies. (...) Another aggravator is the environment and you have to understand that in national terms the environment is very inflexible (...), if you read the São Paulo environmental law you will see that they do not even refer to nitrogen, hence the state of Rio Grande do Sul has always been more catholic than the pope, this is one of the sins of RS and that is also why it is broken. It is not that I am in favour of polluting, it is just that you are in a country, and you have to be in a context of equality for everyone, if you have different parameters, that's when migration starts'. (Interview with a Business Person)

The impressive thing is that an illusion of development is established, due to the industrial visibility of the location and the increase of work positions, regardless of the labour conditions that will affect the environment and the health of the population living in the neighbourhood.

The imposition of multinational companies continues and when there is little time left for the contract to expire, they make new agreements with more requirements. If the government does not accept the proposed agreement, they go to another state, which is already open and flexible to accept the demands. The important thing is to point

\footnotetext{
${ }^{9}$ The possibility is proposed that in the case of risk migration to other states of Brazil; they are not just migrating due to issues of tax incentives, but also for differences in environmental legislation and its enforcement.
}

out that behind these contractual absurdities there is an electoral policy, with which governments advertise local development and use the lack of knowledge of the people in order to continue governing.

This reality allows the questioning of why some regions of Brazil go through very poor conditions of survival. How can we evaluate exploitation or the presence of misery and hunger? How can we think of industries that do not impact the environment and that do not have harmful effects on the health of workers, in the presence of years of unemployment? What should be the attitude of governors? Which process of development should be implemented for consciousness-raising regarding this cycle at a global level?

In effect, under such conditions, the economical situation of Brazil has receded regarding that of developed countries. During the period of 1930 to 1980 , there has been an increase of income per Brazilian inhabitant in respect to the income per inhabitant in the United States, nevertheless a reverse process was generated at the beginning of the 1980s: a tendency that deepened at the beginning of the 1990 s, precisely with the implementation of neoliberal practices.

What is known is that this division of labour, followed by aspects of globalisation of the economy is far from producing a situation of balance in the aspects of worldwide social and economical equality; on the contrary, they will tend to concentrate capital in a few countries that occupy the centre of technological development, to the detriment of regions that suffer from disparities in development.

In particular, the controversies on the phenomenon of globalisation have been proposed. Regarding the case of the Vale do Rio do Sinos, in the industrial sector of tanneries, it is of special interest to verify distortions of globalisation, when considering a more excessive load of environmental liabilities in regions of the world with lower comparative advantages. That is to say, it stimulates one to think that the VS is a victim of unequal globalisation, that the redistribution of the new international division of labour has provided underdeveloped countries with industrial activities with a higher potential of pollution ${ }^{10}$.

This collection of topics is developed ${ }^{11}$ by being careful not to generalise (as the great majority of authors do) in one single division: centre countries and peripheral countries. With the reference mark on Brazil, we will

${ }^{10}$ YOUNG, CEF. and LUSTOSA, MCJ., 2001. The environment and the competitiveness of Brazilian industry. Revista de Economia Contemporânea, vol. 5, no. special, p. 231-259. YOUNG, CEF. Commercial opening, competitiveness and pollution: the behavior of Brazilian industry. Report of a CNPq research, mimeo. YOUNG, CEF., 2000. Pollution and international trade: an empirical analysis of the Brazilian export complex, Rio de Janeiro, Mimeo. YOUNG, CEF. and ANDRADE PEREIRA, A., 2000. Environmental control, competitiveness and international insertion: an analysis of Brazilian industry, In: Twenty-eighth National Meeting of Anpec, Campinas.

${ }^{11}$ Reference for the issue of the migration of risk. 
speak of regions, because a country like this cannot be perceived through a theoretical focus of globality or generalisations, but rather by means of an analysis of the parts. When Guivant (1998b) reviews Beck's theory of globalisation in the book Risk Society, she refers precisely to the author's lack of sensitivity, when generalising from an evolutionary perspective between the society of classes and the society of risks.

With an emphasis on the proposal of Guivant we might say that, when having a notion of Brazilian reality, we should not formulate simplistic concepts; that is to say, since we cannot view globalisation by blocks of western and nonwestern societies (as Beck does in the abovementioned book), we should not consider or generalise "one Brazil", since "there are many Brazils within Brazil".

We cannot consider the limited perception that Beck has of the complexities of the dynamics of globalisation in the relationships between countries from the North and the South and within each one of these countries. The global risk society that Beck analyzes is rooted in his European experience, and maybe more intimately in a German reality. Also when, in his last book (Beck, 2000), he focuses on the flexibilization of labour and the effects of unemployment and identifies them with the brazilianization of the West, we find a simplistic vision of Brazil by not considering it trespassed by distinct and coexisting realities. (Guivant, 2001a, 12 p.)

Moreover, more than just in risk, the peripheral countries live in uncertainty, an uncertainty that extends to the minimal conditions of survival. This ends up by reinforcing the divide in which these societies live. However, also in the so-called developed countries, the description of society as a risk society seems to be inaccurate. Even in those countries, the deterioration of living conditions, the flexibilisation of labour laws, the problems of medical care and social security, the resurgence of some diseases that were considered eradicated, pose a challenge to scientific and technological knowledge generated there. The experiences of the South start being important for the understanding of the new situations in the North. To deny the supremacy of the scientific and technological knowledge of the North and of the actions legitimated by this knowledge means to explore possibilities on how the world can be, and link the knowledge to its context by confronting it with others and building

"a new relationship between the local and the global, between singularity and generality, underlining what Ernesto Laclau called the 'dignity of the specific', and determining the validity of his statements based on the consequences of their involvement with the world" (NUNES, 2005, p. 329).

In view of these theoretical conflicts, we may pose questions such as: What is the phenomenon called globalisation?; Is it a natural and irreversible law?; Is this not part of a political formulation, led by certain economic groups?; And regarding the environment, does it not impose limits to the economic growth of countries, making it, thus, necessary to externalise its impacts?

Santos (2005) discusses globalisation, by presenting it as a multifaceted phenomenon. In this sense, he distinguishes economical globalisation, social globalisation, political globalisation, and cultural globalisation as processes whose hegemonic discourses make the globalisation phenomenon something linear, monolithic and unequivocal, representing the history of the winners told by themselves. However, depending on the way of looking at it, the local does not disappear, and articulates in counter-hegemonic practices that which may also be global.

It is necessary to develop, as I proposed elsewhere (Santos, 1999), a theory of translation that allows the creation of reciprocal intelligibility between different social struggles, to deepen what they have in common so as to promote the interest in translocal alliances and to create abilities for them to effectively take place and prosper (Santos, 2005, p. 74).

Jameson (2001) analyses globalisation especially based on its economical and cultural characteristics. For him, the production of goods is a cultural phenomenon in which products are bought both for their image as for their use, and that a whole industry has emerged for the planning of image and strategy of marketing for goods and companies. Thus, economy converts into a cultural question. However, there is also the movement of culture for the economy that is represented by the entertainment industry (especially the North American one), by the system of patents and by strategies to end self-sufficiency of the peripheral countries in terms of food. In this aspect, culture becomes economy and dictates political agendas.

The evidence is that developed countries and multinational companies, in excellent competing conditions, are those that are most interested in globalisation. There are strong elements of "power" in the economical and productive variables, which allow one to view the comparison between countries and the configuration of the international division of labour and its well-defined categories.

Elements such as lack of democracy and access to technological resources are a typical example of economic power of the so-called developed countries. These, in turn, need abundant natural resources and cheap labour for the development of technology. Based on this logic, they relegate to the developing countries, with a market basically centered on export products, with minimum wages for their workers and an accelerated destruction of their natural resources.

According to Jameson (2001), transnational corporations have been "the first sign and symptom of a new capitalist evolution, feeding political fears that there was a new dual power, that there was a supremacy of these paranational giants over national governments" (JAMESON, 2001, p. 25), with the capacity of devastating national labour 
markets and transferring operations to other locations with cheaper labour being the most concerning aspect of this new transnational power. However, it is possible to say that there is a complicity between states and large corporations. Considering this observation, it is worth taking a close look at multinational corporations ${ }^{12}$.

Furtado (1974) states that international exchanges tend to be unfavourable to countries whose production is of primary products, while accumulation concentrates in industrialised countries. Dos Santos (1973) makes a similar analysis. For him, the movement of capital from one dominant country toward the dominated countries conditions distinct social structures and specific social dynamics within the same production mode. This movement is only possible due to the existence of a global market for goods, capitals and labour. Thus, in the so-called developing countries, the industrialisation process is not oriented toward the constitution of a national economical system, but is rather formed as a complement to the international economical system (Furtado, 1977). Hence, on the one side, the export of capital, credit, technological domination, accumulation of the effect of technological development and production of knowledge persist; and on the other, there are the countries in which the remittance of currency is made, the debtors, the technological subjugation and the use of already objectivated knowledge constitute antagonistic social structures (Dos Santos, 1973).

With the possibility of managing resources in several countries, international transactions are "in the hands" of the multinational companies (Dos Santos, 1973). The relations between these companies and the states constitute, therefore, relations of power. The large companies have interests in influencing local politics in order to facilitate the free entry and the free exit of currencies. As argued by Furtado (1974, p. 35), "the large company controls innovation - the introduction of new processes and new products - into the national companies, which is certainly the most important instrument of international expansion". According to Dos Santos (1973), the multinational corporations tend to act in sectors with a higher economical concentration and with more advanced technology, which they start controlling and monopolising.

And still for Furtado (1974), the acceptance of the American political leadership in the past decades is related to the fact that it was not expressly linked to American interests, but has been presented as an instrument of defense of Western civilization. The privileged minorities of the developing countries try to reproduce the lifestyle of the industrialised countries (Furtado, 1974), thus creating a

\footnotetext{
${ }^{12}$ There is a discussion on the concept of multinational and transnational: the multinational would be a company whose capital originates in one country and that has subsidiaries in other countries, and the transnational would be the company whose capital originates in more than one country and that operates in more than one country. However, this separation is not made in this text, both multinational and transnational are terms used to designate a large corporation that operates in several countries, regardless of the origin of their capital.
}

dominant class within developing countries (Dos Santos, 1973), by characterising the economy-culture interweaving pointed to by Jameson (2001) and determining the flow of goods that ends up by increasing the distance between the rich and the poor within developing countries, and generate the divide of a great portion of the population from this system harnessed to techno-scientific networks.

This method makes developed countries specialists in the production of goods resulting from high technologies; hence, poor countries are left with specialty in the production of goods that depend on raw materials, energy and, above all, on low-cost labour. However, this international division of labour produces, moreover, in Brazil, a dispute between states in order to obtain the location of companies, by believing that by doing so, they collaborate with development, when, in reality, they join a race of exploitation and generation of polluting waste. Referring to the VS, a representative of Public Administration states that the industrialisation is planned logistically in the following manner: "the rich country sells the idea, the emerging country works with the industrial and productive question and the poor country does the dirtiest work, primary work". Such rationale and all that has been developed up until now on the macromicro question, and the danger of conceptual and structural generalities, leads us to wonder if the migration of dirty industries of the south towards other states in the country is part of an environmental conscience that is resistant to pollution or is a strictly economical-business strategy. More than a principle of second modernity, in VS, one perceives the search for opportunities of better markets and of productive freedom.

Another factor that benefits the developed countries is the deficient environmental legislation and control mechanisms of the peripheral countries. The comparative advantages still continue to be perverse regarding environmental legislation, when we observe that there are significant differences between the resolutions and articles of developed and underdeveloped countries. Hence, we might question another point regarding which type of globalisation this one is, that tries to homogenise the conditions of production and market, but does not optimise, in an equal manner, the control mechanisms regarding environmental degradation, which is often the source of economic development. However, this reading should undergo restrictions; that is, the globalisation analysis process of the environment expresses itself in the different arrangements of a world order. Agreements are no longer treated strictly under an economic plan, making companies responsible for the inclusion of the commitment to the environment in their planning and social responsibility.

Young (2001) presents a study that expresses the discrepancy that exists with respect to the inequality of production and the implementation of dirty industries in underdeveloped countries. In the case of Brazil, according to the author, the industries that have grown the most in the last few decades are those that emit a high degree of pollution, reaching $10 \%$ above the average of industrial growth. In these industries, the statistics record that the 
relationship with international trade generates serious problems for the environment; in other words, export products cause pollution that is higher than the average.

Attitudes like the one specified above constitute the basis for the utilitarian plan, according to which migration of dirty industries towards underdeveloped countries would increase worldwide well-being. An interpretation of the theory is that poor countries would have the environmental ravages compensated for by economic growth and in return developed countries would have economic losses in exchange for a healthier environment. It is important to point out that the healthy environment is considered in this perspective not as an element that is inherent to quality of life, but rather as a "luxury". Thus deprived populations should do without this, in exchange for covering basic needs. As mentioned earlier, in 2005, the VS was the region with the highest level of income in Rio Grande do Sul. However, it was in the eighth position regarding sanitation, fifteenth in education and sixteenth in health services. The weight attributed to the variable income assured its position in third place among the regions of RS with respect to the Social-Economical Development Index (FEE, 2009). Therefore, concerns with the variables related to the environment, especially those of sanitation and health services, are relegated to the second plane regarding the development process of the region.

The idea of the global is maintained, and, moreover, in the last few years this has altered the economical, social and political structures. The greatest conflict is established around politics, since the acceptance of a certain industrial investment is the responsibility of the governments: on the one hand, industrial development is linked to the social system (labour relations) and on the other, the latter is the product of alterations (environmental impact). Up to which point are these decisions the responsibility of governments? The conflict extends and governments find themselves in the dilemma of doing things against their principles in order to satisfy a population, or to do it wrongly, with good intentions, within an electoral perspective.

The society of the VS lives with strong principles of first modernity (industrial base), which is the reason why,

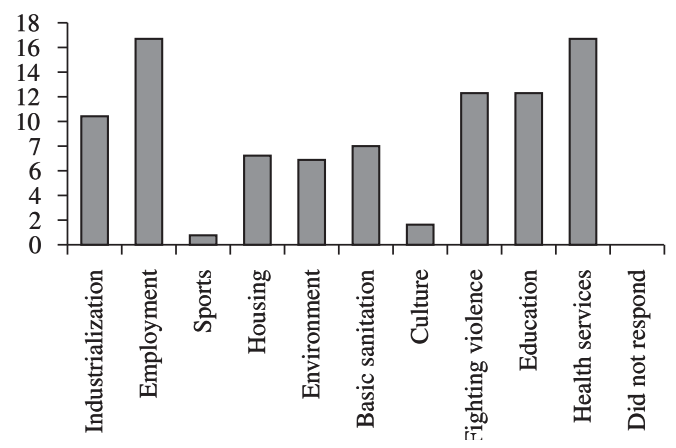

Figure 1. Priority to invest in the VS. Source: Research with the representatives of public administration and the directors, workers, technicians and neighbours of the tanning industries, 2006-2007. Authors' own preparation. although a few politicians are conscious of the risks of industrialisation, it cannot act without causing protests of the advocates of industrial development. In Figure 1 we can observe that there are other problems that concern more than the environment.

Out of ten alternatives, considered by the authors as basic needs of a society, in the VS the environment remained as the eighth need in order of importance, remaining behind culture and sports. On the other hand, we can observe (Table 1) that for the sector of technicians and public administration, the environment is a priority; for the former it comes after health services and for the latter it also occupies a prominent place, only coming after employment, along with education.

The data show that both the technicians that work within industries and those that plan actions (public power) perceive the need to invest in the environment. Perhaps these data are a reflection of the players (public administration and technicians) that are under the highest environmental pressure at present in the VS. The difference is that this supposed pressure does not reach the point of concern, in comparative terms, of the directors of the tanning industries, which continue acting according to the market, and whose priorities are industrialisation, followed by basic sanitation, employment, education and health services (Table 1).

Arguing proceeds toward the fact that there is an initial separation in the curve of economical growth between this growth and environmental development. For such a gap, material development would be indispensable, and, once concrete, it would be in harmony with the element from which it had become dissociated at the beginning of the process. In this logic, we are left to suppose that, at the end of the process at the worldwide level, there would be no more nations willing to sell their environmental assets in exchange for economic development (there would be no peripheral countries in order to maintain the developed capitalists in opulence).

Pochmann (2001) proposes that since the second industrial revolution, it would be improbable that economies lacking financial and technological resources would have access to high development standards. This is due to the fact that technological needs and the needs for energy, for the production of goods and the needs of transformation industries, require resource conditions similar to those of the countries with an industry-based economy, which can only be incremented through merging of capital from several sectors (banking, etc.). In the case of agriculture-based economies, such procedures would be impossible and could only be carried out on future occasions, by the economic maximum regarding cost/benefit over the installation of an industrial plant. One example of compensation is installation close to the sources of raw material. ${ }^{13}$

\footnotetext{
${ }^{13}$ It is a process that is responsible for attracting and rehousing dirty industries towards intermediate or marginal countries, with a deficient environmental legislation, with poor controls and enforcement, with cheap labour and an abundance of natural and energetic resources.
} 
Table 1. Data per interviewed players in respect to the priorities of the VS. ${ }^{1}$

\begin{tabular}{|c|c|c|c|c|c|c|c|c|c|c|c|c|}
\hline \multirow{3}{*}{ Rating } & \multirow{2}{*}{\multicolumn{2}{|c|}{$\begin{array}{c}\text { Workers } \\
\text { Frequency } \\
\end{array}$}} & \multirow{2}{*}{\multicolumn{2}{|c|}{$\begin{array}{c}\begin{array}{c}\text { Public } \\
\text { administration }\end{array} \\
\text { Frequency }\end{array}$}} & \multirow{2}{*}{\multicolumn{2}{|c|}{$\begin{array}{c}\text { Neighbours } \\
\text { Frequency } \\
\end{array}$}} & \multirow{2}{*}{\multicolumn{2}{|c|}{$\begin{array}{l}\text { Directors } \\
\text { Frequency } \\
\end{array}$}} & \multirow{2}{*}{\multicolumn{2}{|c|}{$\begin{array}{l}\text { Technicians } \\
\text { Frequency } \\
\end{array}$}} & \multirow{2}{*}{\multicolumn{2}{|c|}{$\begin{array}{c}\text { Total } \\
\text { Frequency }\end{array}$}} \\
\hline & & & & & & & & & & & & \\
\hline & no. & $\%$ & no. & $\%$ & no. & $\%$ & no. & $\%$ & no. & $\%$ & no. & $\%$ \\
\hline Industrialization & 44 & 11.34 & 30 & 0.56 & 35 & 8.86 & 35 & 19.44 & 14 & 8.00 & 158 & 11.11 \\
\hline Employment & 80 & 20.62 & 47 & 16.55 & 70 & 17.72 & 25 & 13.89 & 27 & 15.43 & 249 & 17.51 \\
\hline Sports & 4 & 1.03 & 7 & 2.46 & 0 & 0.00 & 0 & 0.00 & 0 & 0.00 & 11 & 0.77 \\
\hline Housing & 40 & 10.31 & 24 & 8.45 & 38 & 9.62 & 13 & 7.22 & 0 & 0.00 & 115 & 8.09 \\
\hline Environment & 12 & 3.09 & 38 & 13.38 & 21 & 5.32 & 12 & 6.67 & 29 & 16.57 & 112 & 7.88 \\
\hline Basic sanitation & 4 & 1.03 & 22 & 7.75 & 35 & 8.86 & 29 & 16.11 & 35 & 20.00 & 125 & 8.79 \\
\hline Culture & 16 & 4.12 & 7 & 2.46 & 7 & 1.77 & 0 & 0.00 & 0 & 0.00 & 30 & 2.11 \\
\hline Fighting violence & 64 & 16.49 & 35 & 12.32 & 56 & 14.18 & 18 & 10.00 & 13 & 7.43 & 186 & 13.08 \\
\hline Education & 44 & 11.34 & 38 & 13.38 & 56 & 14.18 & 25 & 13.89 & 22 & 12.57 & 185 & 13.01 \\
\hline Health Services & 80 & 20.62 & 36 & 12.68 & 77 & 19.49 & 23 & 12.78 & 35 & 20.00 & 251 & 17.65 \\
\hline Did not respond & 4 & 1.03 & 0 & 0.00 & 0 & 0.00 & 0 & 0.00 & 0 & 0.00 & 0 & 0.00 \\
\hline Total & 388 & 100 & 284 & 100 & 395 & 100 & 180 & 100 & 175 & 100 & 1422 & 100 \\
\hline
\end{tabular}

${ }^{1}$ Source: Research with the representatives of public administration and the directors, workers, technicians and neighbours of tanning industries, 2006-2007. Authors' own preparation.

Faced with this reality, the question arises: Will peripheral countries that have achieved some industrialisation due to geographical expansion (North American model) have the same success regarding the dynamics of the technological process of the post-industrial era? How many more economical, technological and scientific resources will be necessary to make peripheral economies competitive in their economical profits in the post-Fordean era? Something real is being discussed in education, research and technological development.

Castells (2005) follows this logic when he defends that capital without information and technology is unable to advance and reproduce itself. According to the author, technology and information is the effective way of producing capital and competing with the international market in economical development, by reducing environmental damages as much as possible. In this sense, we ask: Would there be time to complete this plan before the environmental damages of the current model of development prevent any action, with irreversible damage? Even if that happens, what about the question of consumption? And why do developed countries continue to carry out environmental aggressions in their own territory even when they are not focused on primary production?

With the questions posed up to now, can we conclude that harmony between economical development and conservation of the environment (defended by the neoclassical theory) does not materialise, or would we be at the beginning of the process, in which environmental degradation would be indispensable? The fact that becomes most evident in the application of policies based on the focus of the comparative advantages theory is the damage on the environment, when there is negligence in the environmental control policies in favour of competition in the market. Young and Pereira (2000) use examples of this fact when proposing that the commodities export model, with more severe rules of environmental control and environmental protection measures, would account for financial losses. The main evidence is expressed in the environmental subvention of the processes of insertion in international markets ${ }^{14}$.

The conflict that establishes is: Is it possible to sustain that the liberalisation of the economy could reduce environmental damage? The argument, in terms of a positive response, is that the end of import barriers would facilitate the inflow of goods and the replacement of obsolete machines and equipment with other efficient and modern ones, but less polluting and with a higher capacity of exploiting raw material. In this case, the external or internal industries with this equipment would be more competitive and force, through competition, the closing of industries that use less technological and more polluting resources.

Another point to emphasise is that the end of certain tariffs could facilitate the importation of machinery that reduces pollution. The great problem is if this logic is expressed in the difference of imported and exported products. That is to say, in order to finance importation of "clean" goods, made viable by the end of barriers, other goods are exported that have a much higher polluting potential.

Thinking of the importation of less polluting capital goods, there could also be a reduction in the levels of polluting emissions. This is not correct, or at least that is not what Young (1999) shows. In an empirical investigation (in Brazil), the author demonstrates that this importation has shown an improvement in the nature of the goods, but by no means has meant a reduction of pollution emissions.

\footnotetext{
${ }^{14}$ Young and Pereira (2000) develop on which measures of environmental restrictions adopted by regulatory entities would cause an important reduction in exports. The tanning sector of the footwear industry, for example, would reduce its exports by $10 \%$.
} 
Nevertheless, with the end of importation barriers, deindustrialisation emerges, a fact that causes serious social and environmental impacts. Without industry there are no jobs, and without jobs there are no conditions given to the population to invest in the improvement of a healthier environment. The State is also directly responsible and aggravates the situation when it follows a neoliberal ideology and ignores its role as an agent of social wellbeing. This reality is visibly manifest in the constitution of shantytowns in underdeveloped countries, specifically in Brazil. Populations that live in these surroundings find themselves without support from the state and experience diminishing productivity due to the degraded environment. In this sense, they drift away from any possibility of improvement. ${ }^{15}$

The circle becomes vicious; unemployment deteriorates the quality of life and consequently, jeopardises opportunities for work. Young and Pereira (2000) present important data, according to which the poor condition of the periphery damages the environment in an invisible manner. These authors demonstrate that, due to the influence of globalisation, in the 1990s, Brazilian industry increased its production with less workers $(-1 / 4)$. This means that the volume of harmful emissions per employed worker has increased, and at the same time, unemployment has increased.

There is another controversy regarding the issue of importations. Some point to a benefit, albeit reduced, for the environment; but this assumption is outweighed by the fact that someone produces goods with polluting processes, in exchange for the financial gains received from those importing these products ${ }^{16}$. Others counter-argue that the increase of imports causes the imbalance of internal accounts and unemployment, which, as we have seen above, causes environmental degradation in less favoured areas and precludes (or benefits) attitudes by the state in order to solve these problems.

The positive argument in this case would be that the requirements for environmental control would proceed

\footnotetext{
${ }^{15}$ In the case of Brazil, the shantytowns are abandoned by the state, for they are built up on land that is tax-exempt and are spaces that are invaded by the excluded population. They soon form a "parallel command" to that of the government and, in this case, are even more efficient in helping the population with their basic needs. The film City of God opens up the debate on this issue, but the film Cidade dos Homens (City of Men) portrays the social context that creates violence, the contemporary situation of the shantytown and the everyday life of the people who live in a shantytown. While the first film shows the history of institutionalised violence, the second one (Cidade dos Homens) is the portrait of the people who live amidst a civil war. In this film there is an episode that is called "A coroa do Imperador" (The crown of the Emperor), which explains the logic of drug trafficking, and which makes a comparison between the dispute of the shantytowns by the traffickers and the dispute of Europe during the Napoleonic Wars. More recently, another film portrays the situation: Tropa de Elite (2007).

16 One could say that goods are produced with polluting processes that should finance the importation of other "cleaner" products.
}

from the purchasing countries, through the imposition of rigorous environmental standards. Industries would be obliged to search for innovative solutions, which would consume much fewer natural resources. There would also be more rigorous behaviour of consumers in the developed countries, who would become more demanding, by requiring quality stamps, which would make "domestic products" aimed at more competitive markets gradually adapt to the requirements.

According to Young and Lustosa (2000) and Young and Pereira (2000), international companies are more perceptive to business opportunities and more sensitive to clean manufacturing processes; a reason why they do proportionately spend more with environmental impact reduction measures and invest in changes in productive processes in order to reduce such impacts. According to these authors, international companies can contribute towards the adoption of environmental control measures also in the activities of national companies. However, for everything to be perfect, it would be necessary for market conditions to be ideal, without the objections presented at the beginning. The problem would be in the fact that the expansion of this equation to demanding markets would assume an advancement capable of stopping or minimising the effects of markets in which no environmental scruples exist.

The catastrophe of the death of fish in the Sinos River, in October 2006, perfectly illustrates this issue: the international market (mainly European countries) demanded explanations. Below is an excerpt of the statement:

[...] today we have better access to the industries in general, one perceives that [the industrialists] are concerned with the situation of the environment and willing to solve the problems. Our municipality is known as 'pollutant' and therefore we have to change together. As we can see, things reverberate and the fact has been news not only in Brazil but in the whole world, and the consequences have been diverse. A company from Germany (which purchases leather from a factory here in our municipality) has called us and they wanted information on the fact and wanted to know whether or not the factory was related to this fact. [...] The citizen that is anywhere in the world will not purchase leather from those who are polluting, from those who are killing fish; that is to say, industrialists also start perceiving the need to protect themselves and to show that there is environmental work being done. (Interview with a Representative of Public Administration).

Business people and representatives of public administration have shown concern with the situation; but the compiled statements lead us to the following questions: If there had been no fish killing and if the industries had continued with their model of production and treatment, would there be any manifestation from the international market? What are the security mechanisms regarding production, in such distant geographical spaces? Is the 
"quality stamp" a sufficient requirement to say that an industry has "clean" production?

Facts like those mentioned allow us to sustain the idea that international trade or globalisation do not warrant environmental protection in terms of equality in all locations. Hence, for example, the tanneries in the VS that show better waste treatment stations, recognised by the national and international markets, are constantly fined for environmental aggressions and are now accused as being the main responsible parties for the catastrophe of October 2006, which caused the death of more than 100 tons of fish. Can something that causes death and destruction be supported by national and international environmental legislation?

What is perceived as positive is, on the one hand, the legitimacy and need of control resources of national and international environmental institutions and, on the other, a considerable improvement in the requirements of consumers of the developed countries, especially in the last decade. Therefore, change in industries is now a need.

Only patterns of competition that take into consideration the effort for innovation and the authentic gains in productivity will be able to conciliate economical and environmental objectives; countries that easily expose their environmental assets and make great contingents of workers succumb, only establish conditions for competition. The former invest in qualified workers, since losses of raw material and energy at their final destination are minimized and so access to markets with better purchasing power and higher requirements, willing to pay for better and differentiated products, will be facilitated.

Again, the problem emerges around inequality and who will have the possibility of success, since the nature of this type of market is restricted to products with a high aggregated technological value, in which underdeveloped countries have insignificant participation.

As mentioned previously, innovation in the leather and footwear industry in the VS is systematised, and corresponds to solutions of problems. This encumbers the generation of innovations, since the inexistence of a formal innovative process jeopardises the accumulation and systematisation of the knowledge necessary for growth in the technological capacity of companies. However, the heterogeneity of the companies in the sector makes it possible that there are companies that appropriate and generate technologies for the production of leathers, footwear and components and place themselves in the international competitive scenario as cutting-edge companies, capable of reorienting their strategy toward differentiation, while other companies still have serious problems of management, which even prevent the generation and dissemination of organisational innovations. In this sense, some companies have invested in the differentiation of their products, especially in terms of design, style and brand name of ladies shoes, as an attempt to recover market competitiveness. This new strategic orientation requires the generation of technological and organisational innovations.
Technological innovations in the leather-footwear industry find support in countless research institutions that act in the region, such as, for example, the Instituto Brasileiro de Tecnologia do Couro, Calçado e Artefatos (Brazilian Institute of Technology for Leather, Footwear and Artifacts) (IBTeC), which is responsible both for research in new materials and for part of the normalisation of the sector, and the Centro Tecnológico do Couro (Leather Technological Center) of the Serviço Nacional de Aprendizagem Industrial (National Industrial Learning Service) (CT Couro - SENAI), which is responsible for research, technical assistance and technological education. Other teaching and research institutions, such as the Centro Universitário Feevale (Feevale University Center) and the Universidade do Vale do Rio dos Sinos (University of the Vale do Rio dos Sinos) are also active in the sector. Moreover, organisations such as the Associação Comercial, Industrial e de Serviços de Novo Hamburgo, Campo Bom e Estância Velha (Commercial, Industrial and Service Association of Novo Hamburgo) (ACI - NH/ $\mathrm{CB} / \mathrm{EV}$ ), and the Associação Brasileira de Empresas de Componentes para Couro, Calçados e Artefatos (Brazilian Association of Companies for Components for Leather, Footwear and Artifacts) (ASSINTECAL), the Associação Brasileira das Indústrias de Calçados (Brazilian Association of Footwear Industries) (ABICALÇADOS) have been active for a long time in the sector, by promoting initiatives in political coordination and representation, aiming at the qualification of the industry in terms of corporate management. However, partial results of research by the authors, still under way, indicate that the leather and footwear industry shows serious deficiencies regarding management capacity, which hinders the generation and dissemination of organisational innovations (innovations in management programs and organisational structures). This, in turn, hinders not only the international insertion of the companies in qualified markets, but also exerts direct reflection on environmental innovation, whose changes in productive processes and products require, very often, a corporate restructuring that goes from the reorganisation and creation of new areas within the organisation to the design of processes and products, down to the relationship with suppliers and customers.

What is observed, after this development, is that there would be no decrease in the differences of the comparative advantages of the countries with the strengthening of commercial exchange. Thus the solution of environmental problems could not take place in a second development period, when, at a given time, economic growth absorbed by international trade would allow the allocation of resources to such a demand, and the tendency towards its intensification is observed, more often than not. So, would the market be the solution to this problem? Does the conservation of the "seedling" by ecologists depend on insertion into the world market, or will there be the perpetuation of the stratification of the world economy and economical, military and cultural power of certain countries which will take upon themselves to subdue peripheral nations with 
the accumulation of environmental losses in a constant degradation in their quality of life?

It has been increasingly proven that the impact of the globalised economy on the environment is also global and, therefore, the responsibility belongs to all countries. The environmental liabilities of poor countries finance clean and sustainable environments in developed countries. It is sure that neoliberal theory (or with a few differences, the theory of ecological modernization or still, sustainable development theory ${ }^{17}$ ) proposes that greater economical development is compatible with the conservation of the environment, becomes increasingly doubtful, and we might say that we would be closer to solving the conflict with its negation.

For some propositions, the radicalisation of globalisation and its economical, social and ecological effects are the result of a process in which powerful nations exploit other nations which, due to several deficiencies, are left without any alternative. Finally, one of the main hypotheses discussed lately is that, on the occasion of predatory activities on the environmental assets of a certain country (or now in a globalised dimension), the most powerful nations would conserve or promote their own environmental assets.

\section{Conclusion}

While approaching a local analysis based on the foundations of globalisation, as developed throughout the present text, when looking at the formation of the Vale do Rio do Sinos, one has established that this society has, since its origin, prioritised industrialisation as the primary way of development. The risks of industrialisation to health and the environment have always been annulled by economical gains and by population growth of the regions, as symbols of progress. For many decades, the government has been coherent with the principles and wishes of the private sector (growth of industry), and, to a great extent, to the collective (offers of employment). People have been conditioned by an industrial culture that has not saved efforts to be considered the largest one in Brazil in the "industrial leather segment". Previously one did not think of the environment, it used to be taken for granted that natural resources were in excellent condition; everyone was winning: the employees with good wages and working options; the industrialists with good profits and the government was considered the best of these to foment the development of the region. As a consequence, now, governments "pay the debt" of the irresponsibility of the past: from the triumph of employment to the failure of unemployment, from environmental preservation to destruction, and even more serious, in the face of attitudes that jeopardise employment, they have generated the rejection by the community. The pollution of an industry can be accepted by governments in order to ensure popularity,

\footnotetext{
${ }^{17}$ See the second and third chapter of the thesis "Indifference or Unsatisfied Needs? The Question of Technological Risk in the Vale do Rio do Sinos", which discusses the conceptual approximation of Ecological Modernization and Sustainable Development.
}

since, when there are protest movements, they are more articulate to manifest themselves in the defense of work positions, than against the problems of pollution.

It is also perceived that the main problem of the globalised structure is that there is a moralism, or rather a set of "false morals" in the principles of clean production. In the case of the tanneries in the VS, the exportation of the product (hides) is produced even when almost $90 \%$ of the pollution remains in the place of origin. What measures of clean production do purchasing countries adopt alongside the producing countries? A risk migration is clearly evidenced, which for many business people may be involuntary; the important fact is the product and the price, regardless of its origin.

The data obtained also evidence the internal social inequality and competitiveness of the country. The migration of dirty industries, in the case of Brazil, is generated among the states; the transfer of dirty industries has an impact on the levels of poverty, the tanneries are migrating from the south toward the north of the country. The benefits of this migration are suicidal, since they employ in one region the same amount of people that they unemploy in another; those who win are the industrialists who migrate to improve profits, regardless of the pollution and the effects on the environment.

The cycle does not stop, that is to say, what happens to the reality of the north of Brazil has already happened to the south, and with the development of the European countries. Governments look for immediate development; in the case of Brazil, natural resources, cheap labour, the conditions of legislation and, above all, the need for and the belief in progress through industrial development, are vital to attract the investments of dirty industries: future natural resources are burned in order to remedy the ruin of the present (Sachs). Risk becomes a profitable business: great capitals with legal territory for exploitation solving the problems of the vulnerable population. One identifies private capital that uses the public environment, with two consequences: the maximisation of benefits and the socialisation of the environmental damage.

The fact that there is irresponsibility and lack of commitment with the environment is reflected in the scarce treatment of industrial waste by the tanneries, even though they own the best treatment stations in Brazil. As we have seen, this is no longer only a perception, it is reality; during the last environmental catastrophe (October 2006), in which more than 100 tons of fish died, the industries most accused of environmental crime were the tanneries; moreover, the highest volume of product found in the analyses of the fish was chromium, a chemical that is widely used in the tanning industry ${ }^{18}$. Another factor is that the complaint of

\footnotetext{
${ }^{18}$ In the interview, a representative of an NGO says that the Sinos River is operating to the limit. In the analysis of the fish it was noticed that they were hemorrhagic, which indicates contamination by chemicals, as they did not have an open gall; which indicates that death was not due to lack of oxygenation.
} 
the industrialists was generalised as to the cost of waste treatment; the declarations evidenced economical and not environmental conservation concern, a fact that, along with other factors, is causing the migration of these industries to other states, where there are supposedly fewer legal requirements.

Thus, this economical policy affects the population that live in the most vulnerable areas, a reason why they will either identify or relegate the risks of the industrial complex when enjoying the benefits and income obtained with employment. One perceives that the Brazilian society has not overcome the principles of the first modernity (Beck). The greatest concern refers to wealth and its distribution.

Nevertheless, it is judged ${ }^{19}$ that, within this industrial development, there is an unsatisfied need. That is to say, this market is going through a great crisis, resulting in a considerable increase in unemployment in the region. Those who are working do not run the risk of talking about discontent out of fear of losing their position. The rule is "not to complain where you earn your bread" (interview with a worker), even though they are discontent with this development, they depend on it to meet their basic survival needs.

I conclude this paragraph with the proposition of Baumann (1992), when demonstrating that risks may affect people at different moments and intensities; according to the author, what we intend for others is something that most often, we cannot carry out ourselves. Example: We criticise the pollution caused by individual transportation, but we resist using public transport ${ }^{20}$.

\footnotetext{
19 These data have not been recorded in the interviews or in the questionnaire, but it is relevant to propose that part of the population is unhappy with the activity of the tanneries, especially because of illnesses and health problems diagnosed in the workers. There is a report on an investigation carried out by Cicourel (1968) on the police in the USA, which dealt with a comparative study between some states regarding juvenile violence. After the work had been carried out, they published a book and sent it to the police headquarters, where many said, in a tone of repentance, that if they had been sure of secrecy regarding their names, they would have said a lot more in the reports. Thus, in the field research it is important to obtain some data that will never be mentioned. Cicourel made reference to this case on the "Investiture as Doctor Honoris Causa" in his speech delivered at the Universidad Complutense de Madrid (June 19, 2008).

${ }^{20}$ For some, the proposal of Bauman is pessimistic, since the author proposes a control of the risk society based on moral principles that are different from modernity. Everyone should be morally responsible for their own ignorance, that is to say, the highest aphorism is in an ethics that determines an uncertain future, something that cannot even be evidenced by scientific certainties. The role of legislators and experts would be that of interpreters, since they cannot place themselves as guardians of moral values. The author's hope is that the moral conscience of humanity wakes up, since up to this moment it has been anesthetized.
}

\section{References}

BAUMAN, Z. 1992. Intimations of Postmodernity. New York: Rutledge.

_, 2005. La era de la información: economía, sociedad y cultura. In: La Sociedad en Red. 3 ed. Madrid: Alianza Editorial. (Spanish version by Carmen Martínez Gimeno and Jesús Alborés).

DOS SANTOS, T., 1973. Imperialismo y empresas multinacionales. Buenos Aires: Editorial Galerna.

DEÁK, C., 2000. Seminário Internacional de Globalização e Estrutura Urbana, 9-10 September 1997. São Paulo: Faculdade de Artquitetura e Urbanismo, Universidade de São Paulo.

FERRÉ, JLG., 2003. Mundialización y Medio Ambiente. REDUR, no. 1, p. $71-80$

FURTADO, C., 1974. O mito do desenvolvimento. 2 ed. Rio de Janeiro: Paz e Terra.

_, 1977. Prefácio à nova economia política. 3 ed. Rio de Janeiro: Paz e Terra.

GUIVANT, J., 1998. Conflitos e negociações nas políticas de controle ambiental: o caso da suinocultura em Santa Catarina. Ambiente \& Sociedade, ano 1, no. 2.

_, 2001. Global food risks: environmental and health concerns in Brazil. In: HOGA, DJ. and TOLMASQUIM, MT. (org.). Human Dimensions of Global Environmental Change: Brazilian Perspective. Rio de Janeiro: Academia Brasileira de Ciências. p. 249-277.

JAMESON, F., 2001. A cultura do dinheiro: ensaios sobre a globalização. Petrópolis: Vozes.

NUNES, JA., 2005. Teoria crítica, cultura e ciência: o(s) espaço(s) e o(s) conhecimento(s) da globalização. In: SANTOS, B. (org.). 3 ed. A globalização e as ciências sociais. São Paulo: Cortez.

POCHMANN, M., 2001. A década dos mitos. Rio de Janeiro: Ed. Contexto.

SANTOS, BS., 2005. Os processos da globalização. In: SANTOS, BS. (org.). 3 ed. A globalização e as ciências sociais. São Paulo: Cortez.

YOUNG, CEF. and PEREIRA, A., 2000. Controle ambiental, competitividade e inserção internacional: uma análise da indústria brasileira. In: XXVIII National Meeting of ANPEC, Campinas.

YOUNG, CEF. and LUSTOSA, MCJ., 2000. Meio ambiente e competitividade da indústria brasileira. Revista de Economia Contemporânea, vol. 5, no. Especial, p. 231-259.

Secretaria do Meio Ambiente. Companhia Ambiental do Estado de São Paulo - CETESB, 2005. Available from: www.cetesb. sp.gov.br

Fundação de Economia e Estatística - FEE, (s.d.). Available from: http://www.fee.tche.br/

Relação Anual de Informação Social - RAIS, 2008. Available from: www.rais.gov.br. 